\title{
PADOMJU LATVIJAS RŪPNIECĪBAS ATJAUNOŠANA UN ATTĪSTĪBA 20. GADSIMTA 40.-50. GADOS: BŪVMATERIĀLU RAŽOŠANAS NOZARES PIEMËRS
}

\author{
ALEKSANDRS PETROVS \\ Mg. hist., LNA Latvijas Valsts arhīva dokumentu saglabāšanas \\ nodaḷas galvenais fondu glabātājs \\ E-pasts: aleksandrs.petrovs@arhivi.gov.Iv
}

\begin{abstract}
ANOTĀCIJA
Raksta mērḳis ir sniegt ieskatu galvenajās Latvijas PSR rūpniecības attīstības iezīmēs un problēmās pēckara gados, ilustrējot to ar vienas no republikas rūpniecības "šaurajām vietām" - būvmateriālu ražošanas nozares - piemēru.

Pētījumā, kas kḷuva par pamatu šīs publikācijas tapšanai, balstoties uz arhīva materiāliem, tika apzināta Latvijas PSR tautsaimniecības struktūra un tās atjaunošanas procesi no Otrā pasaules kara beigām līdz 1953. gadam, šim mērḳim padzị̣ināti izpētot vienu no tās nozarēm - būvmateriālu rūpniecību, īpašu uzmanību pievēršot ražošanas procesam, ražotajai produkcijai un galvenajiem darbības rādītājiem.

Pētījuma rezultāti parāda - lai gan būvmateriālu ražošanai bija piešḳirta stratēgiskā nozīme un tā bija strauji jāattīsta, realitātē tās stāvoklis pētāmajā laika posmā bija prioritārai tautsaimniecības nozarei neatbilstošs.
\end{abstract}

Atslēgas vārdi: Latvijas PSR, tautsaimniecība, ekonomika, rūpniecība, ražošana, būvmateriāli.

\section{IEVADS}

Tautsaimniecībai, neatnemamai jebkuras valsts un tautas vēstures daḷai, diemžēl tradicionāli nav pievērsta tik liela vēsturnieku uzmanība kā, piemēram, politiskām un militārām pagātnes norisēm. Daḷēji to varētu izskaidrot ar faktu, ka vēl salīdzinoši nesen tautsaimniecības vēsture vairāk nodarbināja ekonomikas (vai politiskās ekonomijas) pētniekus un bija 
viṇu kompetences lokā. Tomēr mūsdienās līdz ar visas tautsaimniecības struktūras principiālām izmaiņām kādreizējie saimniekošanas principi un ekonomiskā politika kopumā organiski kḷuvuši par vēsturnieku izpētes lauku. Turklāt nozīmīgu devumu saimniecības vēstures izpēte var sniegt arī mūsu valsts sociālās vēstures attīstībā, jo pievērsties lauksaimniecībai un rūpniecībai, iedziḷinoties procesos, kas notikuši šajās jomās, nozīmē ielūkoties sfērā, kurā atškịīibā no militārām lietām un arī politikas bija nodarbināts absolūtais iedzīvotāju vairākums jebkurā valstī un politiskajā režīmā. No otras puses, tautsaimniecība ir joma, kas nav atdalāma no politikas. Kā ir teikusi Latvijas eksprezidente Vaira Vīḳe-Freiberga: “Ekonomiskie apstākḷi vienmēr ir bijuši ciešā mijiedarbē ar politisko vidi un sabiedrības struktūru, tādēḷ Latvijas un tās iedzīvotāju saimnieciskā situācija un iespējas ir cieši saaugušas ar latviešu tautas likteņiem un vēsturisko attīstību" (Krūmiņš 2017). Šim apgalvojumam var piekrist, jo, neṇemot vērā ekonomisko faktoru, nekādus fundamentālus politiskus mērķus nevar ne izvirzīt, ne panākt, ne arī saprast, tādēḷ ka tieši ekonomiskā bāze nosaka, cik lielā mērā jebkādi nopietni politiskie mērḳi ir īstenojami. Šajā ziṇā kā ekonomika un politika, kā saimniecība un sabiedrība, tā arī politiskā, saimnieciskā un sociālā vēsture ir vienotas un nav mehāniski atdalāmas viena no otras.

Otrā pasaules kara, karadarbības un nacistu īstenotās saimnieciskās politikas rezultātā Latvijas teritorijas saimnieciskais potenciāls bija ievērojami cietis, kas lielākoties ir saistīts ar vietējā darbaspēka zaudējumiem sakarā ar represijām, mobilizāciju un piespiedu vervēšanu darbiem Vācijā (nemaz nerunājot par to, ka esošie un vēl strādājošie rūpnieciskie uzṇēmumi, kā arī lauksaimniecība darbojās Vācijas un tās karaspēka, nevis vietējo vajadzību apmierināšanai), taču par smagāko triecienu kḷuva vācu okupantu mēéginājumi izmantot t. s. "izdedzinātās zemes taktiku". No Latvijas teritorijas atkāpjoties, visas iespējamās vērtības - izejvielas, gatavo produkciju, mašīnas un iekārtas - nacisti centās aizsūtīt uz Vāciju, bet tas, kas nebija paņemams līdzi, pēc iespējas tika iznīcināts - piemēram, tika daḷēji izdemolēta K,eguma HES un citas (kopā 52) spēkstacijas, 5790 rūpnieciskie uzñēmumi un pat to tukšie korpusi, dzelzcel̦šs, tilti un citi infrastruktūras objekti (Aizsilnieks 1968, 950; Krastiņš 2018, 159).

Tāpat kauju un bombardēšanas rezultātā manāmi samazinājās Latvijas lielāko pilsētu dzīvojamais fonds. Ja Rīgā situācija bija vēl kaut cik ciešama - tā neatgriezeniski zaudēja "tikai" 19 \% no pirmskara valstij piederošā dzīvojamā fonda (Cīṇa 1945, 91), piemēram, Liepāja zaudēja 41,6 \% un Jelgava - 91 \% apdzīvojamās platības (Komunists 1946, 214), neskaitot nosacīti dzīvošanai derīgās ēkas ar izsistiem logiem, cauriem jumtiem un bojātām komunikācijām. Desmiti, ja ne simti tūkstoši cilvēku pārdzīvoja karu un nacistu okupāciju, bet zaudēja savu mājokli. 
Pēc Latvijas PSR ĀRK aplēsēm, kopumā republikai tika nodarīti zaudējumi aptuveni 20 mljrd. rubḷu apmērā 1941. gada cenu izteiksmē; lai gan mūsdienu pētnieki pārsvarā nepiekrīt šim skaitlim, pieminot arī citu - 660 milj. ASV dolāru (Bleiere et al. 2005, 324). Lai kā būtu, neviens neapstrīd faktu, ka, lai gan Latvijas teritorijā kara zaudējumi bija nesalīdzināmi mazāki nekā, piemēram, blakus esošajās Baltkrievijas vai Ukrainas PSR, tomēr arī ievērojama daļa Latvijas pilsētu un ciemu māju, uzñēmumu, tiltu, elektrostaciju u. c. infrastruktūras objektu kara gaitā tika pārvērsti drupās.

Lai uzsāktu tautsaimniecības, komunālās un arī militārās saimniecības pēckara atjaunošanas procesu, padomju varai bija vitāli svarīgi pēc iespējas ātrāk "ievadīt pareizās sliedēs" būvmateriālu ražošanu - uzdevums, kurš, kā izrādās, nemaz nebija tik viegls, lai gan jau pirms kara Latvijas Republikā šì nozare bija diezgan labi attīstìta - 1939. gadā Latvijā tika saražots 123 milj. kieǵelu un $164000 \mathrm{t}$ cementa (Latvijas PSR statistikas tabulas 1940, 141), bet tādas ražotnes kā "Rīgas ǵipsis", Bolderājas būvkeramikas fabrika un cementa fabrika Brocēnos skaitijāas savam laikam visai modernas un augsti mehanizētas - to, bez šaubām, labi apzinājās arī vācieši, jo, atbrīvojot Latvijas teritoriju no Vācijas karaspēka, izrādījās, ka šo fabriku tehnologiskais aprīkojums vai nu pazuda (Cīna 1946, 228), vai tika apzināti sabojāts (Eiduks 1962, 197-198).

Būvmateriālu rūpniecības atjaunošana tika deklarēta par visaugstāko prioritāti līdzās energoapgādes atjaunošanai un kurināmā ražošanai - tā bija oficiāli ierakstīta Tautsaimniecības atjaunošanas un attīstības piecgades plāna likumā, atspoguḷojās vietējā mēroga padomju valdības un Komunistiskās partijas amatpersonu runās un rīkojumos, preses materiālos, galu galā, arī veselais saprāts pasaka priekšā, ka bez būvmateriāliem nekāda atjaunošana notikt vienkārši nevar.

Diemžēl no saimnieciskās vēstures skatpunkta, pēckara desmitgades periods Latvijā ir pētīts ievērojami mazāk nekā vēlākie: detalizētu ziņu par tajā notiekošajiem procesiem, saražoto produkciju un uzṇēmumiem ir mazāk kā padomju, tā arī mūsdienu literatūrā, lai gan, pētot tieši šo posmu, var iedziḷināties problēmās, kuras piedzīvoja padomju sistēma savas nostiprināšanās periodā Latvijas teritorijā, saprast, kādi faktori veicināja Latvijas sovjetizāciju un industrializāciju, kādi - kavēja. Līdzšinējā historiogrāfija par Staliina laika rūpniecību Latvijā un sevišķi par būvmateriālu rūpniecību (liekas, atsevišḳu vēsturnieku darbu par to vispār nav) nav atzīstama par izsmeḷošu - kā viens no nedaudziem, ja ne vienīgais darbs, kurā tika mēǵināts konceptuāli apskatīt Latvijas teritorijas industrializācijas problēmas un izvērtēt tās sekas ilgtermiņā, ir minama Dr. hist. Irēnas Šneideres 1989. gada monogrāfija. Tomēr kopumā līdz šim un joprojām pētnieki, apskatot attiecīgo jautājumu, ne tikai nefokusējas uz saimniecisko aspektu, tā vietā izceḷot iepriekš minēto procesu politisko dimensiju, 
bet arī lielā mērā paši atrodas politiskās konjunktūras ietekmē - kā padomju darbos Latvijas PSR sociālistiskā industrializācija tika vērtēta viennozīmīgi pozitīvi jebkurā aspektā, bet netika plaši atzītas un pietiekami analizētas kḷūdas, nepilnības un nejēdzības, kas pavadīja šo procesu, tā arī lielākajā daḷā trimdas un mūsdienu literatūras sociālistiskā industrializācija ir aprakstīta pavirši un tās kā viennozīmīga l,aunuma vērtējums tajā ir gandrīz vai aksiomātisks.

Par pamata avotiem dotās tēmas izpētei var kalpot tādi LNA Latvijas Valsts arhīvā glabājamie dokumenti kā LK(b)P/LKP CK ${ }^{1}$ lēmumi un sarakste par būvniecību un būvmateriālu rūpniecību (PA-101. f.), LPSR Būvmateriālu rūpniecības (1398. f.) un Vietējās rūpniecības (378. f.) tautas ko-

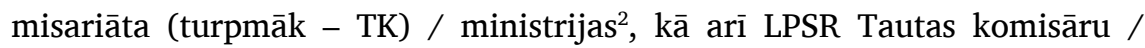
Ministru padomes (270. f.) un Valsts plāna komitejas (693. f.) dokumenti, konkrēto uzṇēmumu LKP pirmorganizācijas sapulču protokoli, kā arī Krievijas arhīvos glabātie dokumenti, kas attiecas uz PSRS Būvmateriālu rūpniecības TK/ministriju (RGAE, 8248. f.) un tās glavkiem - galvenajām pārvaldēm (piem., RGAE, 8245. f. - Glavzapadcement jeb Rietumu rajonu cementa rūpniecības galvenā pārvalde). Svarīgs sekundārs avots ir arī tā laika prese - nenoliedzot faktu, ka tajā sniegtā informācija neiztika bez zināmas tendenciozitātes un koncentrējās uz pozitīvo aspektu izcelšanu (kas izriet no preses kā propagandas līdzekḷa darbības mērḳa), kā arī saprotamu iemeslu dēḷ kritika tajā nevarēja būt vērsta pret politisko un saimniecisko valsts kursu, tomēr noteiktas problēmas, ar kurām saskārās šo izdevumu mērḳauditorija - parastie strādnieki, zemnieki un kalpotāji, tajā skaitā būvmateriālu ražošanas nozarē nodarbinātie -, ir konstatējamas un diezgan bieži izceltas. Visai konkrētu gadījumu apraksts (par vienā vai otrā uzñēmumā veiktajiem paplašināšanas vai rekonstrukcijas darbiem, darbinieku disciplīnas pārkāpumiem, bet it īpaši par nekvalitatīvas produkcijas izlaišanu un augsto brāķa īpatsvaru, kuru daudzkārt aprakstīja un nosodīja daudz bargāk tieši presē, nevis arhīvā glabājamos dokumentos) savukārt liecina par to, ka presē sniegtajai informācijai piemita ne tikai virspusīgs un propagandisks raksturs. Uz presē publicētiem datiem, protams, nevar pilnīgi paḷauties, tomēr tie ir izmantojami atsevišksu aspektu dziḷākai izpētei, kā arī salīdzinošai analīzei, savstarpēji pārbaudot gan dažādos rakstos un izdevumos, gan arhīva materiālos sniegto informāciju.

\section{BŪVMATERIĀLU RAŽOŠANAS NOZARES STRUKTŪRA UN SVARĪGĀKIE UZṆĒMUMI}

Pēc nacistiskās Vācijas karaspēka padzī̌sanas no Latvijas teritorijas visa tautsaimniecība atgriezās padomju institūciju pārvaldē. Tāpat kā citu 
nozaru uzṇēmumi, arī būvmateriālu rūpnīcas un fabrikas tika sadalītas pēc to lieluma un svarīguma:

1. vissavienïbas nozīmes (PSRS Būvmateriālu rūpniecības TK / ministrijas tiešā pakḷautībā);

2. republikāniskajos (pakḷauti Latvijas PSR Būvmateriālu rūpniecības TK / ministrijai);

3. vietējos, kuri nonāca Latvijas PSR Vietējās rūpniecības TK / ministrijas pakḷautībā.

Pirmajai kategorijai atbilstošo būvmateriālu uzņēmumu Latvijas PSR uzreiz pēc kara nebija, tomēr 1951. gadā atjaunojusies un strauji attīstījusies republikas cementa ražošana (Rīgas un Brocēnu cementa rūpnīcā) saskaṇā ar PSRS AP Prezidija lēmumu pilnībā nonāca vissavienības orgāna - PSRS Būvmateriālu rūpniecības ministrijas Rietumu rajonu cementa rūpniecības galvenās pārvaldes (Glavzapadcement) - pakḷautībā (LNA-LVA, 1398-1-159, 158).

1945. gada 31. martā dibinātā Celtniecības un būvmateriālu rūpniecības TK sistēmā pēc kara nonāca 49 būvmateriālu ražošanas uzṇēmumi (LNALVA, 1398-1-145, 58-59), no kuriem tikai piecos bija daḷeji atjaunota ražošana (LNA-LVA, PA-101-6-23, 122), savukārt 1945. gada beigās strādāja jau 30 uzñēmumi (LNA-LVA, 1398-1-145, 58-59), bet 1948. gadā - gandrīz visi, izņemot Brocēnu šifera fabriku, Brocēnu cementa fabrikas trešo kārtu un dažus ḳiegeẹnīcu cehus (LNA-LVA, 1398-1-190, 3). 1946. gadā iepriekš minēto TK sadalīja divās atsevišķās ministrijās un Latvijas PSR būvmateriālu lielražošanu pārṇēma Latvijas PSR Būvmateriālu rūpniecības ministrija, savukārt sīkie lauku kalı̣,u un ķiegeḷcepḷi nonāca Vietējās rūpniecības ministrijas pārvaldībā, kur tos apvienoja rūpkombinātos. Lielākie un svarīgākie būvmateriālu uzñēmumi pēc kara bija: Kalnciema un Brocēnu kombināts (attiecīgi ḳieǵeḷu un cementa ražošana), "Riǵipsis" (sausā apmetuma ražošana), "Segums" (jumtu papes ražošana), kā arī "Sarkandaugava" (stikla ražošana), turklāt jau 1946. gadā tika plānota pirmās jaunās rūpnīcas izbūve Bolderājā, kur no vietējām smiltīm ievērojamā daudzumā ražotu silikātkiegẹelus, - to pabeidza 1952. gada vidū.

Bez iepriekš minētajām uzṇēmumu grupām Latvijas teritorijā funkcionēja arī atsevišķas būvmateriālu ražotnes, kas nebija pakḷautas ne LPSR vai PSRS Būvmateriālu, ne Vietējās rūpniecības ministrijai. Piemēram, viena no 60.-70. gados lielākajām ḳieǵeḷu un būvkeramikas rūpnīcām "Spartaks" līdz 1948. gadam bija Kara jūrniecības celtniecības pārvaldes Nr. 5 uzṇēmums (Zujeva) un pārsvarā izpildīja kara flotes pasūtijumus - flotes bāzes celtniecība Daugavgrīvā, Bolderājas Ziemas ostas akvatorijas gultnes padziḷināšana u. tml. - un arī piedalījās uzspridzinātās Daugavas krastmalas atjaunošanā (LNA-LVA, PA-101-11-82, 1-4), savukārt Krustpils kieǵeḷu rūpnīca, lai gan institucionāli bija pakḷauta Būvmateriālu rūpniecības ministrijai, tika 
iznomāta Latvijas dzelzceḷa Militārās celtniecības darbu pārvaldei (LNALVA, PA-101-9-82, 80). Daži ar būvniecību saistītie uzņēmumi, galvenokārt būvdetalı un būvkonstrukciju ražotnes, atradās Dzivokḷu un civilās celtniecības ministrijas, kā arī Komunālās saimniecības ministrijas sistēmā, savukārt būvmateriālus šì jēdziena plašā nozīmē ražoja arī Meža rūpniecības ministrijas (lietkoksni), PSRS Ķīmiskās rūpniecības ministrijas Ķīmiskās rūpniecības GP (silikātus) u. c. uzñēmumi. Prakse parādīja, ka tāda institucionāla sadrumstalotība îsti nenāca nozarei ${ }^{3}$ par labu, dažkārt provocējot interešu konfliktus dažādu resoru cinņā par resursiem ${ }^{4}$ apstākḷ,os, kad būtu log̣iskāk tos koncentrēt vienuviet.

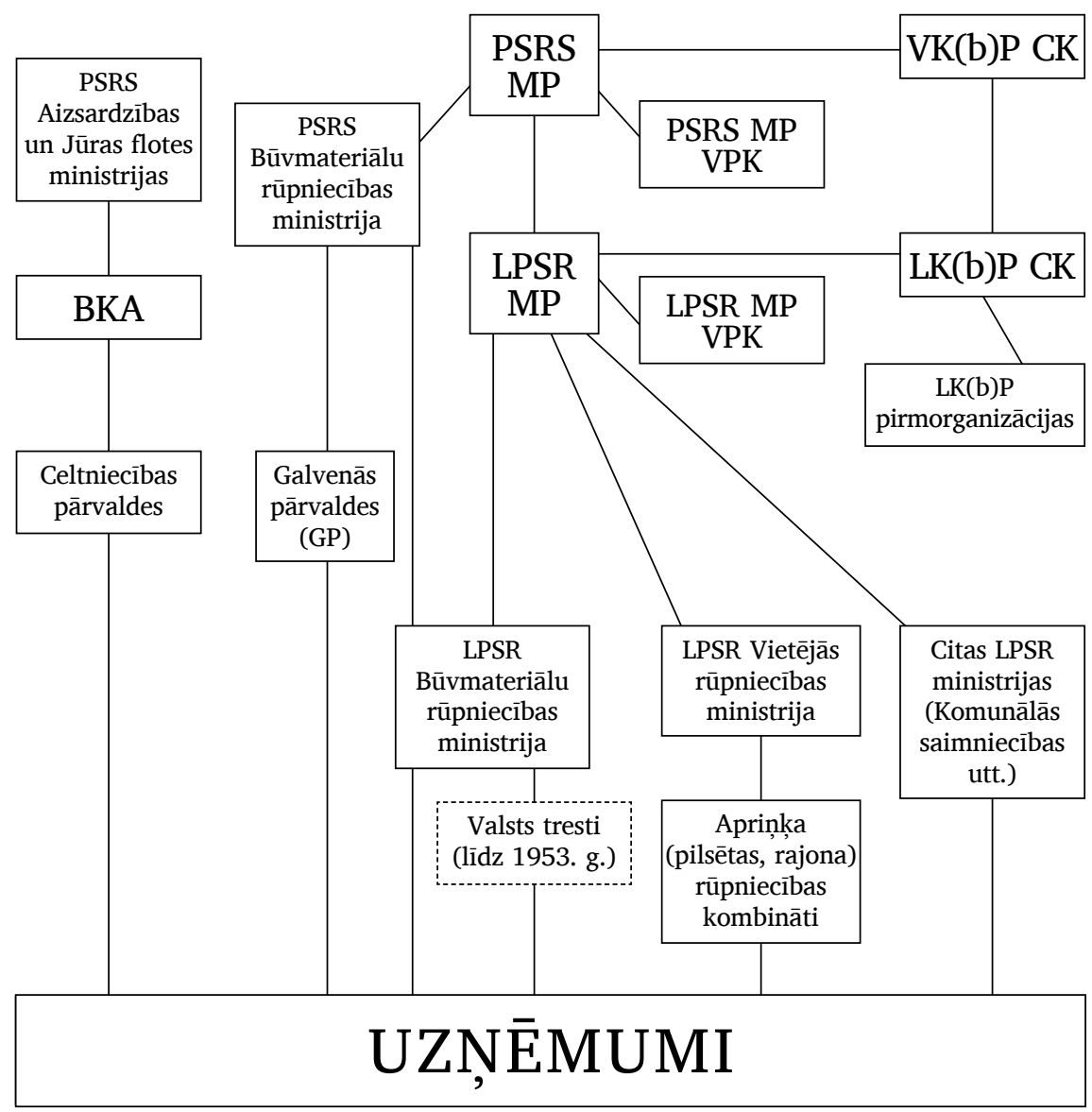

1. attēls. Latvijas PSR būvmateriālu ražošanas uzṇēmumu nosacītā pārvaldes shēma (20. gs. 50. g. pirmā puse). Autors: A. Petrovs

Figure 1. Conventional scheme of the institutional structure of the Latvian SSR building material enterprises (the first half of the 1950s). Author: A. Petrovs 


\section{GALVENIE DARBĪBAS RĀDĪTĀJI}

Uzreiz pēc Otrā pasaules kara būvmateriālu ražošana Latvijas teritorijā maz atgādināja 1939. vai 1940. gada rūpnieciskās ražošanas līmeni, bet vairāk līdzinājās 18. gadsimta situācijai pirms Industriālās revolūcijas. Daudzi avoti liecina par smagiem nozarei nodarītajiem zaudējumiem (LNA-LVA, 1398-1-144, 8; LNA-LVA, 1398-1-146, 25; u. c.). Veicot pēckara revīziju, tika konstatēts, ka no 56 uzṇēmumiem, kas 1941. gadā bija reǵistrēti Būvmateriālu rūpniecības TK sistēmā, kara gaitā cietuši pilnīgi visi, turklāt 100 \% ražošanas jaudas zaudējumu esot cietuši 50 uzñēmumi, $95 \%$ - viens uzṇēmums, $80 \%$ - viens, $50 \%$ - trīs un $20 \%$ - viens uzṇēmums (LNA-LVA, 1398-1-191, 12-14, 39-40), ${ }^{5}$ turklāt lielu satricinājumu piedzīvoja ne tikai ražošanas materiāltehniskā bāze, bet arī darba kultūra, disciplīna un ražošanas tradīcijas. Apstākḷos, kad darbaspēka trūkuma dēl ražošanas procesos tika iesaistīti nekad līdz šim ar to nesaistīti cilvēki, kadru politika ieguva arī apmācīšanas un audzināšanas darba iezīmes turklāt tas nekādā ziṇā nebija vieglāks par sapostīto ēku vai ražošanas iekārtu atjaunošanu.

Pirmajos pēckara gados padomju republikām visādā ziṇā bija jāpaḷaujas uz vietējiem resursiem. Ražošanas līdzekḷu kontekstā tas nozīmēja visa iespējamā pēc kara palikušā aprīkojuma un inventāra remontu un pārtaisīšanu ar vienīgo mērḳi - nodrošināt to ekspluatāciju, lai gan par primāro ražošanas metodi šajā laikā nenoliedzami kḷuva cilvēku roku darbs. Pirmo impulsu normāla, savam laikmetam atbilstoša ražošanas procesa atjaunošanai deva no uzvarētās Vācijas atvestās iekārtas, bet to, protams, ne tuvu nepietika visiem sapostītajiem uzn̄ēmumiem.

1949. gadā aizsākās Kalnciema kombināta rekonstrukcija ar mērḳi nodrošināt tajā ḳieǵeḷu ražošanu visu gadu (iepriekš tas bija sezonāls darbs, bet ārpus sezonas būvkeramikas uzṇēmumi ražoja dažādus blakusproduktus, piemēram, māla traukus). Tolaik kombināts arī pirmo reizi saṇēma padomju ražojuma ražošanas līdzekḷus - spiednes, ekskavatorus utt. Tādējādi 1950. gadā būvmateriālu rūpniecības kopprodukts Latvijas PSR, salīdzinot ar 1946. gada stāvokli, pieauga vien 1,85 reizes un tikko sasniedza 1940. gada līmeni (salīdzinājumam, elektroenerğētikas kopprodukts 1950. gadā pārsniedza 1940. gada līmeni 2,5 reizes, bet mašīnbūves un metālapstrādes - 11,5 reizes), kas liecina par ārkārtīgi lēnu nozares atkopšanās tempu, pat salīdzinot ar neprioritārām vieglās rūpniecības nozarēm.

Zināmā mērā situāciju paglāba Bolderājas silikātḳieǵeḷu rūpnīcas nodošana ekspluatācijā 1952. gada jūnijā - tikai pēc tam, 1953. gadā, Latvijas PSR izdevās sasniegt saražoto ķieǵeḷu (neapšaubāmi, 20. gadsimta pirmās puses vissvarīgākā būvmateriāla Latvijas teritorijā) pirmskara ražošanas apjomu. 
1. tabula. Galveno Latvijas PSR rūpniecības nozaru kopprodukcijas izaugsme 1946.-1950. g., salīdzinot ar 1940. g. Autors: A. Drīzulis (ar A. Petrova papildinājumu)

Table 1. The growth of gross production of the Latvian SSR main industry sectors in 1946-1950 (compared with 1940). Author: A. Drīzulis (with addendum by A. Petrovs)

\begin{tabular}{|c|c|c|c|}
\hline & \multicolumn{2}{|c|}{$\begin{array}{c}\text { Kopprodukcija } \\
(1940 . \text { g. }=100)\end{array}$} & \multirow{2}{*}{$\begin{array}{c}\text { Dinamikas } \\
\text { indekss } \\
\text { (1946.-1950. g.) }\end{array}$} \\
\hline & 1946. g. & 1950. g. & \\
\hline Mašīnbūve un metālapstrāde & 266 & 1157 & 4,35 \\
\hline Vieglā rūpniecība & 54 & 205 & 3,79 \\
\hline Elektroenerğētika & 100 & 236 & 2,36 \\
\hline Kurināmā rūpniecība & 172 & 362 & 2,10 \\
\hline Būvmateriālu rūpniecība & 66 & 122 & 1,85 \\
\hline Visa rūpniecība & 85 & 303 & 3,56 \\
\hline
\end{tabular}

Avots: LNA-LVA, 1398-1-146, 3; LNA-LVA, 1398-1-150, 44; LNA-LVA, 1398-1-157, 2; Drīzulis 1986, 32

Daudz raitāk gāja ar tāda neaizvietojama būvmateriāla ražošanu kā logu stikls, kura galvenais ražotājs Latvijas teritorijā bija fabrika "Sarkandaugava", kas savu zvaigžņu stundu piedzīvoja jau 1946.-1947. g., sasniedzot virkni PSRS un pat pasaules rekordu, kāpinot vienas savas Furko mašīnas izstrādi no 60 augstas kvalitātes stikla lentes metriem stundā līdz $97 \mathrm{~m} / \mathrm{h}$ 1946. gada septembrī un 146 m/h 1947. gadā, kamēr līdzšinējais amerikāņu stiklinieku rekords esot bijis 90 m/h (Pionieris 1946, 33; Brīvā Venta 1948, 86; Padomju Jaunatne 1947, 23). Šis sasniegums tika atspoguḷots pat tā laika trimdas presē, turklāt bez tai parasti piemītošās ironijas un izsmiekla (Latviešu Ziṇas 1946, 101), bet dzimtenē tam tika veltīti literārie darbi (Karogs 1946, 11/12). Turklāt rekorda autori - fabrikas galvenais inženieris Pāvels Čeredničenko un stahanovietis Žanis Zuimačs personiski san,ēma Stalina prēmiju. Tomēr jau 50. gadu sākumā, nomainoties uzn,ēmuma direktoram, "Sarkandaugavas" produkcijas kvalitāte dramatiski kritās - kas atrada precīzu atspogul,ojumu citas trimdinieku avīzes raksta nosaukumā "No pasaules rekorda līdz brāḳim" (Latvija 1952, 37). Šis precedents vēlreiz apstiprina tēzi par to, cik daudz visdažādāko faktoru var ietekmēt kāda uzṇēmuma produkcijas kvalitāti un cik īsā laikā tā var kardināli mainīties.

Tāpat arī citu būvmateriālu kvalitāte mēdza svārstīties atkarībā gan no ražotāja, gan no produkcijas veida, gan izejvielu kvalitātes un virknes citu 


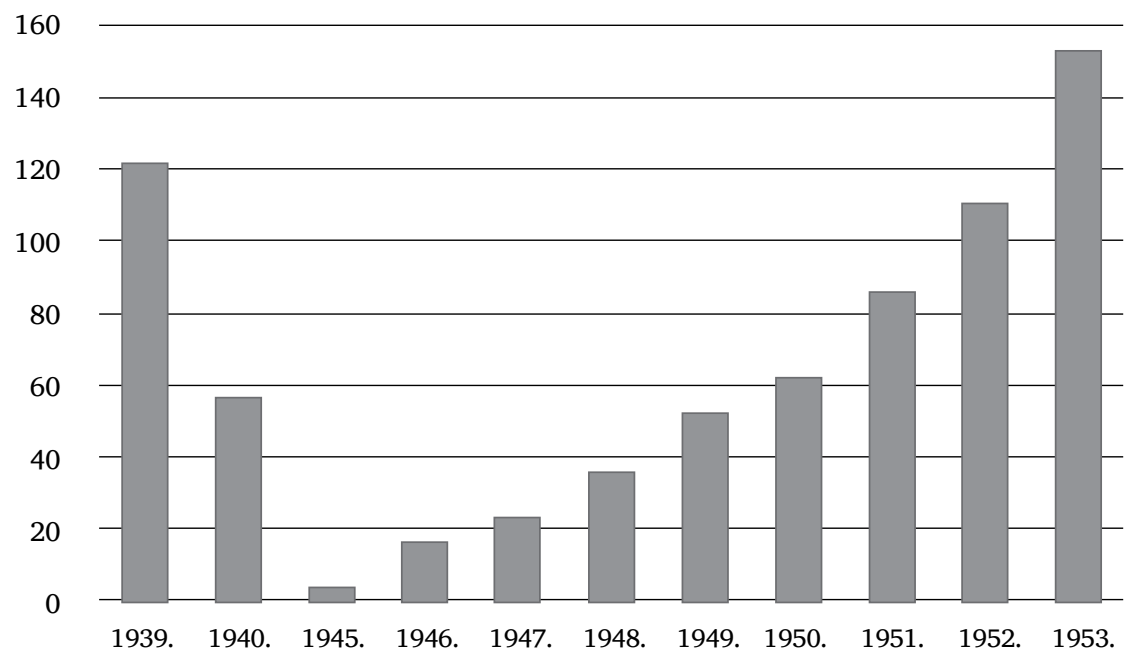

* - No 1945. lìdz 1953. gadam: bez Vietējās rūpniecỉbas TK / ministrijai pakḷauto sīko ceplu produkcijas

2. attēls. Svarīgākā būvmateriāla ražošanas apjomi LR un LPSR naturālā izteiksmē (1939.-1940., 1945.-1953. g.): apdedzinātie ķieǵeḷi (visu veidu), milj. gab. Autors: A. Petrovs

Figure 2. Production of the main building materials by volume in the Republic of Latvia and the Latvian SSR (1939-1940, 1945-1953): fired bricks (full range), mn pcs. Author: A. Petrovs

Avots: Latvijas PSR statistikas tabulas, 141; LNA-LVA, 1398-1-145, 48; LNA-LVA, 1398-1-146, 179; LNA-LVA, 1398-1-150, 109; LNA-LVA, 1398-1-153, 420-421; LNALVA, 1398-1-155, 165; LNA-LVA, 1398-1-157, 149; LNA-LVA, 1398-1-159, 129-130; LNA-LVA, 1398-1-161, 100; LNA-LVA, 1398-1-163, 69; LNA-LVA, 1398-1-186, 3.

faktoru. Piemēram, republikas lepnums - Rīgas gipša fabrika - turpināja izcilā sausā apmetuma jeb ǵipša plākšņu ražošanu, līdz pat 1949. gadam būdama vienīgā šì produkta ražotāja visā Padomju Savienībā (Ritenberga, Dombrovska 1968, 18). Visai augstas kvalitātes esot bijis arī cements, kura ražošanu pārṇēma vissavienības orgāni, un šīferis - viens no galvenajiem cementa izstrādājumiem. Par azbesta, otrās galvenās šîfera sastāvdaḷas, kaitīgumu cilvēka organismam tolaik vēl neviens nezināja.

Diezgan strauji attīstījās arī jaunu būvmateriālu ražošanas tehnoloǵiju apguve - ja 1944. gada beigās no vāciešiem atbrīvotajos uzn̄ēmumos ražoja vien septiņus dažādus produkcijas veidus, tad 1953. gadā - jau vairāk par 50. Pie interesantākajiem jauna veida būvmateriāliem var minēt siporeksu jeb gāzbetonu, tajā skaitā stiegroto, kā arī gípšsilikāta k,ieǵeḷus - par tiem ir atseviškss interesants stāsts: 1952. gadā Sauriešu gipša rūpnīcā esot izlaista šĩ pavisam jaunā būvmateriāla eksperimentālā partija. Presē tika ziņots, ka jaunā tipa ḳieǵẹ̦i atšḳiras no parastajiem silikātḳieǵeḷiem ar daudz lielāku 
salcietību un mehānisko izturību, kā arī tiem neesot vajadzīga ne žāvēšana, ne apdedzināšana (Socialisticheskij put' 1952, 136). Tomēr masveida ražošanā novatoriskie ķieǵeḷi nezināmu iemeslu dēḷ tā arī nenonāca, un nekādu papildu informāciju par šo gadījumu un minētajiem ḳieǵeḷiem pagaidām nav izdevies atrast.

Protams, ne tuvu ne visi augstākās kvalitātes materiāli tika ražoti vietējām vajadzībām - it īpaši, kad Latvijas PSR tautsaimniecībā beidzās "pēckara atjaunošanas posms" (ap 1950. gadu) un par galveno būvmateriālu rūpniecības mērḳi kḷuva jau sociālistiskās industrializācijas un kolektivizācijas materiālās bāzes nodrošināšana. Rūpnīcu korpusiem un kolhozu ēkām nebija vajadzīgi dārgi materiāli, arī to sortimentu varēja ierobežot līdz minimumam. Kopš 50. gadu sākuma Latvijas PSR uzñēmumi, tāpat kā citu padomju republiku ražotnes, ar sauso apmetumu, keramiskajām apdares flīzēm, ugunsizturīgajiem k̦ieǵel̦iem u. c. kvalitatīviem materiāliem apgādāja tā sauktās "lielās komunisma celtnes", piemēram, Maskavas Valsts universitātes ēku, Kuibiševas HES vai Galveno Turkmēnijas kanālu (Cīn,a 1951, 106; Cīn,a 1952, 13; Latvju Ziņas 1951, 5), bet ar pēc īpaša pasūtījuma ražotiem blokiem nodrošināja pat Maskavas Kremḷa atjaunošanas darbus (LNA-LVA, 1398-1-153, 421).

\section{SECINĀJUMI}

Apskatot iepriekš minētos piemērus, nevar nepamanīt divas pretējas tendences būvmateriālu ražošanas attīstībā pēckara Latvijas PSR: no vienas puses, neskatoties uz objektīvo svarīgumu, tā bija viena no rūpniecības nozarēm, kas atkopās vislēnāk, faktiski bremzējot celtniecību visā republikā īpaši akūti tas bija jūtams dzīvojamo ēku būvniecībā, kad dažās pilsētās, piemēram, Liepājā un Jelgavā, vietējās komunālās saimniecības iestādes ātrāk apguva būvmateriālu ražošanu no būvgružiem, nekā sagaidīja normālus materiālus no ražotājiem (Cīnna 1947, 193; Cīṇa 1949, 99; Komunists 1948, 57). No otras puses, dažas šīs jomas apakšnozares, kā stikla un ǵipša ražošana, jau pirmajos pēckara gados attīstījās pat daudz straujāk nekā Latvijas Republikas laikos.

Apkopojot nozares uzṇēmumu finansiālos rādītājus, tika konstatēts, ka no "plānoti nerentablās" nozares par ienesīgu Latvijas PSR būvmateriālu rūpniecība pārtapa ap 1950. gadu, bet 1953. gadā no 25 ministrijas uzñēmumiem ar zaudējumiem strādāja tikai septiṇi, tajā skaitā jaundibinātais Ogres karjers un Bolderājas silikātkieǵel̦u fabrika (tā rentabilitātes slieksni sasniedza 1959. gadā), turklāt lielāko peḷnu turpināja dot "Sarkandaugava" (4,5 milj. rubl̦u) un "Riǵipsis" (5,5 milj. rubḷu) (LNA-LVA, 1398-1-145, 9-10; LNA-LVA, 1398-1-146, 10; LNA-LVA, 1398-1-150, 120; LNA-LVA, 
1398-1-153, 17; LNA-LVA, 1398-1-155, 56; LNA-LVA, 1398-1-157, 8; LNA-LVA, 1398-1-159, 51; LNA-LVA, 1398-1-161, 53; LNA-LVA, 13981-163, 37).

Viens no pētījuma pamata problēmjautājumiem - vai būvmateriālu ražošanas nozares piemērs pietiekami labi reprezentē visas Latvijas PSR rūpniecības stāvokli pētāmajā laika posmā, faktiski tā arī palika atklāts. No vienas puses, šĩs nozares stāvoklis patiešām var kalpot par uzskatāmu piemēru tām grūtībām un problēmām, ar kurām saskārās padomju saimniecība pēckara krīzes apstākḷos - darbaspēka, ražošanas līdzekḷu un resursu trūkums, kapitālieguldījumu nesabalansētība, ne vienmēr prasmīga pārvalde utt. - turklāt dažas no iezīmēm, ņemot vērā pašsaprotamo vispārējo nepieciešamību pēc šīs nozares produkcijas, ir redzamas pat skaidrāk nekā citās jomās; no otras puses, Padomju Latvijas būvmateriālu rūpniecības atjaunošanas un attīstības gaitu nevar dēvēt par visai tipisku gadījumu kamēr dažu atsevišķu celtniecības un apdares materiālu ražošana noritēja priekšzīmīgi visas PSRS mērogā, citu - būvḳieǵeḷu - ražotṇu darbības rādītāji bija vieni no sliktākajiem salīdzinājumā ar visiem citiem republikas uzñēmumiem. Dažādu Padomju Savienības reǵionu, tautsaimniecības nozaru un pat vienas nozares apakšnozaru nevienmērīgie attīstības tempi neḷauj pilnā mērā attiecināt izpētīto piemēru uz Latvijas PSR vai PSRS rūpniecību kopumā, bet liek uzdot jautājumu par to, kas īsti šos tempus noteica plāns, kapitālieguldījumu apjoms, darba apstākḷi vai arī kādi citi faktori. Lai uz to atbildētu, turpmāk vēl padarāms milzīgs darbs avotu apzināšanā, izvērtēšanā un izpētē.

\section{SAĪSINĀJUMI}

AP - Augstākā Padome

ASV - Amerikas Savienotās Valstis

ĀRK - Ārkārtējā republikāniskā komisija

BKA - Baltijas kara apgabals

CK - Centrālā komiteja

GP - Galvenā pārvalde (glavks)

HES - hidroelektrostacija

IeM - Iekšlietu ministrija

LK(b)P/LKP - Latvijas Komunistiskā (boḷ̌seviku) partija / Latvijas Komunistiskā partija

LNA-LVA - Latvijas Nacionālā arhīva Latvijas Valsts arhīvs

LPSR - Latvijas Padomju Sociālistiskā Republika

LR - Latvijas Republika

MP - Ministru Padome

PSR - Padomju Sociālistiskā Republika

PSRS - Padomju Sociālistisko Republiku Savienība 
RGAE - Krievijas Valsts ekonomikas arhīvs (krievu val. - Rossijskij gosudarstvennyij arhiv ekonomiki)

SSR - Soviet Socialist Republic (anglu val.)

TK - Tautas komisariāts

TKP - Tautas Komisāru Padome

VPK - Valsts plāna komiteja

ZVA - Zonālais valsts arhīvs

\section{IZMANTOTIE AVOTI UN LITERATŪRA NEPUBLICÉTIE AVOTI}

IeM Karagūstekņu nometņu pārvaldes priekšnieka pulkveža Krastina vēstule LK(b)P CK Sevišḳā sektora vadītājam Kurbatovam par karagūstekṇu darbaspēka izmantošanu Krustpils kieǵeḷu rūpnīcā [krievu val.], 15.10.1946. Latvijas Nacionālā arhìva Latvijas Valsts arhìvs (Rīga, turpmāk: LNA-LVA), PA-101-9-82, 80. lp.

Kara jūrniecības celtniecības pārvaldes Nr. 5 galvenā inženiera Kosoja vēstule LK(b)P CK sekretāram celtniecības jautājumos I. Šilovam par trūkumiem būvmontāžas darbu plāna izpildē [krievu val.], 02.01.1948. LNA-LVA, PA-101-11-82, 1.-5. lp.

Latvijas PSR Būvmateriālu rūpniecības ministrijas Centrāāā grāmatvedība. Celtniecības un būvmateriālu rūpniecības TK 1945. gada pārskats [krievu val.], 1946. LNA-LVA, 1398-1-145.

Latvijas PSR Būvmateriālu rūpniecības ministrijas Centrālā grāmatvedība. Ministrijas 1946. gada koppārskats [krievu val.], 1947. LNA-LVA, 1398-1-146.

Latvijas PSR Būvmateriālu rūpniecības ministrijas Centrālā grāmatvedība. Ministrijas 1947. gada koppārskats [krievu val.], 1948. LNA-LVA, 1398-1-150.

Latvijas PSR Būvmateriālu rūpniecības ministrijas Centrālā grāmatvedība. Ministrijas 1948. gada koppārskats [krievu val.], 1949. LNA-LVA, 1398-1-153.

Latvijas PSR Būvmateriālu rūpniecības ministrijas Centrālā grāmatvedība. Ministrijas 1949. gada koppārskats [krievu val.], 1950. LNA-LVA, 1398-1-155.

Latvijas PSR Būvmateriālu rūpniecības ministrijas Centrālā grāmatvedība. Ministrijas 1950. gada koppārskats [krievu val.], 1951. LNA-LVA, 1398-1-157.

Latvijas PSR Būvmateriālu rūpniecības ministrijas Centrālā grāmatvedība. Ministrijas 1951. gada koppārskats [krievu val.], 1952. LNA-LVA, 1398-1-159.

Latvijas PSR Būvmateriālu rūpniecības ministrijas Centrālā grāmatvedība. Ministrijas 1952. gada koppārskats [krievu val.], 1953. LNA-LVA, 1398-1-161.

Latvijas PSR Būvmateriālu rūpniecības ministrijas Centrālā grāmatvedība. Ministrijas 1953. gada koppārskats [krievu val.], 1954. LNA-LVA, 1398-1-163.

Latvijas PSR Būvmateriālu rūpniecības ministrijas Plānošanas-ekonomikas dạa. Ministrijas atskaite par būvmateriālu izlaides plāna izpildi 1944.-1948. g. (LK(b)P Centrālkomitejai) [krievu val.], [1948]. LNA-LVA, 1398-1-190.

Latvijas PSR TKP Celtniecības un būvmateriālu rūpniecības GP Centrālā grāmatvedība. 1944. gada pārskats [krievu val.], 1945. LNA-LVA, 1398-1-144.

Latvijas PSR TKP Celtniecības un būvmateriālu rūpniecības GP pamatuzñēmumu raksturojums [krievu val.], 1944. LNA-LVA, PA-101-6-23, 122. lp.

Latvijas PSR TKP Celtniecības un būvmateriālu rūpniecības GP Plānošanas-ekonomikas daḷa. Latvijas PSR būvmateriālu ražošanas perspektīvais plāns 1944.-1947. g. ar paskaidrojumu [krievu val.], [1944]. LNA-LVA, 1398-1-186. 
Latvijas PSR TKP Celtniecības un būvmateriālu rūpniecības GP Plānošanas-ekonomikas daḷ. Pārskats par vācu fašistisko uzbrucēju TK uzṇēmumiem nodarīto zaudējumu [krievu val.], 1945. LNA-LVA, 1398-1-191.

LK(b)P CK sekretāra J. Kalnbērziņa vēstule VK(b)P CK sekretāram G. Maḷenkovam par ostās esošo materiālu nodošanu Latvijas PSR Būvmateriālu rūpniecības TK [krievu val.], 06.02.1946. LNA-LVA, PA-101-9-82, 5.-8. 1p.

\section{PUBLICĒTIE AVOTI}

B. a., 1945. Latvijas PSR dzīvokḷu un komunālās saimniecības darbinieku aktīva sanāksme. Cìna, 91, 4.

B. a., 1946. Latvijas stachanovieši uzstādījuši pasaules rekordu. Latviešu Zinas, 101, 2.

B. a., 1946. Sagatavosim dzivvokḷus ziemai. Komunists, 214, 1.

B. a., 1946. Ved atpakal vācu okupantu nolaupītās mašīnas. Cīna, 228, 4.

B. a., 1948. Jaunās technikas izcilie radītāji. Brīvā Venta, 86, 1-2.

B. a., 1951. Ko izved no Latvijas uz Turkmeniju. Latvju Zinas, 5, 1, 5.

B. a., 1952. No pasaules rekorda līdz brāḳim. Latvija, 37, 4.

B. a., 1952. Novye vidy stroimaterialov. Socialisticheskij put', 136, 4.

B. a., 1952. Šiferis - lielajām komunisma celtnēm. Cīna, 13, 1.

Civjans, G., 1947. LPSR Augstākās Padomes deputatu kandidati: Žanis Zuimačs. Padomju Jaunatne, 23, 2.

Dagda, J., 1947. Paplašina būvmaterialu aizvietotāju ražošanu. Cīna, 193, 2.

Deglavs, F., 1948. Latvijas rūpniecības stāvoklis un turpmākās attīstības perspektīvas. Karogs, 1, 92.

Efojs, J., 1946. Nodrošināt ķieǵeḷu ražošanas plāna izpildi. Cinna, 119, 3.

Kacena, V., 1946. Cīṇa ar stiklu. Karogs, 11/12, 1026-1035.

Kalns, R., 1948. Būvmateriali no ražošanas atkritumiem. Komunists, 57, 2.

Kunnoss, G., 1949. Būvdrupas - būvmaterialu izejviela. Cīna, 99.

Latvijas PSR statistikas tabulas (1940). Rīga: Latvijas PSR Tautsaimniecības statistikas pārvalde, 223 lpp.

Liepājs, V., 1951. Būvmateriali lielajām komunisma celtnēm. Cīna, 106, 4.

Likums, Z., 1946. Pasaules rekords. Pionieris, 33, 3.

Zujeva, R., b. g. Rūpniecības attīstība Jelgavas pilsētā 50.-60. gados. [Jelgava:] Jelgavas ZVA. Pieejams: https://www.arhivi.gov.lv/files/files/Digitalas\%20publikacijas/ Rupnieciba_Jelgava_1950_196_gados.pdf [Skatīts 01.09.2020.]

\section{LITERATŪRA}

Aizsilnieks, A., 1968. Latvijas saimniecības vēsture: 1914-1945. Stokholma: Daugava.

Bleiere D., Butulis I., Feldmanis I., Stranga A., Zunda A., 2005. Latvijas vēsture: 20. gadsimts. Rìga: Jumava.

Drīzulis, A. (red.), 1986. Latvijas PSR vēsture, 2. sēj. Rīga: Zinātne, 210-234.

Eiduks, J., Grosvalds, I., 1962. Cementa rūpniecības iesākums un attīstība Latvijas PSR teritorijā līdz 1941. gadam. No: Panovko, J. (atb. red.). Par tehnikas vēsturi Latvijas PSR, III sēj. Rīga: Latvijas PSR Zinātṇu akadēmijas izdevniecība, 149-194.

Krastiņš, E., 2018. Latvijas rūpniecība XIX-XXI gadsimtā: vēsturiski ekonomiska apcere. Rīga: Jumava.

Krūmiņš, G. (sast.), 2017. Latvijas tautsaimniecỉbas vēsture. Rīga: Jumava. 
Ritenberga, V., Dombrovska, V., 1968. Ķìmija Latvijā agrāk un tagad. Rīga: Zinātne. Šneidere, I., 1989. Socialisticheskaja industrializacija v Latvii: hod, itogi, problemy. Rīga: Zinātne.

\section{ATTÉLU, TABULU SARAKSTS}

1. attēls. Latvijas PSR būvmateriālu ražošanas uzṇēmumu nosacītā pārvaldes shēma (20. gs. 50. g. pirmā puse). Autors: A. Petrovs

Figure 1. Conventional scheme of the institutional structure of the Latvian SSR building-material enterprises (the first half of the 1950s). Author: A. Petrovs

1. tabula. Galveno Latvijas PSR rūpniecības nozaru kopprodukcijas izaugsme 1946.-1950. g., salīdzinot ar 1940. g. Autori: A. Drīzulis (ar A. Petrova papildinājumu)

Table 1. The growth of gross production of the Latvian SSR main industry sectors in 1946-1950 (compared with 1940). Author: A. Drīzulis (with addendum by A. Petrovs)

2. attēls. Svarīgāko būvmateriālu ražošanas apjomi LR un LPSR naturālā izteiksmē (1939.-1940., 1945.-1953. g.): apdedzinātie ķieǵeḷi (visu veidu), milj. gab. Autors: A. Petrovs

Figure 2. Production of the main building materials by volume in the Republic of Latvia and the Latvian SSR (1939-1940, 1945-1953): fired bricks (full range), mn pcs. Author: A. Petrovs

\section{ATSAUCES UN PIEZİMES}

${ }^{1}$ Lēmums par valdošās partijas nosaukuma maiņu no Vissavienïbas Komunistiskā (bolšseviku) partija $(V K(b) P)$ uz Padomju Savienibas Komunistiskā partija (PSKP) tika pieñemts partijas XIX kongresā (1952. g. oktobrī) un, pašsaprotami, bija saistošs arī republikas partijām.

${ }^{2}$ PSRS Tautas komisariāti tika pārdēvēti par ministrijām 1946. gada administratīvajā reformā.

${ }^{3}$ Būvmateriālu rūpniecības produkcijas apjoms 1947. gadā deva vien 6 \% no visas Latvijas PSR rūpniecības kopprodukcijas (Karogs 1948, 1), bet 1950. gadā no visa republikas rūpniecībā nodarbināto skaita būvmateriālu ražošanas uzṇēmumu darbinieki veidoja tikai 3,8 \% (Krastiņš 2018, 186).

${ }^{4}$ Piemēram, 1946. g. 21. maija "Cīņas" numurā, spriežot par Kalnciema k̦ieǵeḷu rūpnīcu grupas neapmierinošajiem darba rādītājiem, tika uzsvērts, ka "galvenais iemesls [tam] - trūkst elektromotoru un ekskavātoru, kuṛu Būvmateriālu rūpniecības ministrija iedevusi pagaidlietošanai Rīgas jūṛas būvju trestam, bet pēdējais nesteidzas atdot atpakaḷ" un "arī iztrūkstošie motori ķieǵeḷūūpniecības trestam ar Būvmateriālu rūpniecības ministrijas rīkojumu atņemti un aizsūtīti uz Sauriešu gipša karjeru un siporeksa rūpnīcu".

Cita zīmīgā liecība tam ir J. Kalnbērziṇa 1946. gada 6. februāra slepenā vēstule G. Maḷenkovam, kurā viņš prasa pieškirt daḷu no Vācijas atvestām rūpnieciskajām iekārtām Latvijas PSR būvmateriālu rūpniecības vajadzībām: "[...] Okupācijas un vācu karaspēka atkāpšanās no Latvijas teritorijas gaitā būvmateriālu rūpniecības uzn̄ēmumi tika gandrīz pilnīgi sagrauti, bet lielākā daḷa to aprīkojuma izvesta uz Vāciju. Ar lielām grūtībām, pateicoties vietējiem resursiem, Latvijas PSR izdevās 
daḷēji atjaunot būvmateriālu rūpniecību, kura nestrādā ar pilnu jaudu. [..] Ar pašu spēkiem Latvijas PSR nav spējīga atjaunot sagrauto rūpniecību atbilstošā aprīkojuma dēḷ. [..] Turklāt Liepājas /Lībavas/ un Ventspils /Vindavas/ ostās atrodas un turpina ienākt PSRS Būvmateriālu rūpniecības TK adresētas iekārtas un materiāli no Vācijas, kuras iegūstot [Latvijas Būvmateriālu rūpniecības TK] varētu nodot ekspluatācijā tādas lielās būvmateriālu rūpnīcas kā Brocēnu cementa un šîfera rūpnīca, [...] Kalnciema k̦ieğeḷu kombināts [..] u. c. [..] Lūdzu Jūsu rīkojumu PSRS Būvmateriālu rūpniecības TK par Liepājas un Ventspils ostās esošo aprīkojumu nodošanu Latvijas PSR Būvmateriālu rūpniecības TK [..]" (LNA-LVA, PA-101-9-82, 5)

${ }^{5} 100$ \% ražošanas jaudas zaudējums nozīmē, ka bez kapitālremonta uzn̄ēmums nevar atjaunot ražošanu. Par iemeslu tam bija ražošanas iekārtu un/vai dzinēju dal̦ēja vai pilnīga izvešana, sabojāšana vai iznīcināšana, kā arī ražošanas korpusiem nodarītie būtiskie bojājumi, kas nebija savienojami ar ražošanas turpināšanu. No Cēsu kieǵeḷu rūpnīcas, kuras ražošanas jaudas zaudējums tika vērtēts $80 \%$ apmērā, tika izvesta daḷa no iekārtām un dzinējiem, bet tās èkas nebija cietušas. No $50 \%$ apmērā cietušajiem kaḷ,ku cepliem bija izvests inventārs un instrumenti, bet Apes cepḷa $20 \%$ zaudējumi ir saistīti vienīgi ar dạ̣ējiem cepḷa ēkas bojājumiem. 


\title{
INDUSTRIAL RECOVERY AND DEVELOPMENT OF SOVIET LATVIA IN THE 1940s-1950s: THE EXAMPLE OF BUILDING MATERIALS PRODUCTION SECTOR
}

\author{
ALEKSANDRS PETROVS \\ Mg. hist., senior archivist at the Department of Document Preservation, \\ Latvian National Archives, Latvian State Archive \\ E-mail: aleksandrs.petrovs@arhivi.gov.lv
}

\begin{abstract}
The purpose of this paper is to introduce the main trends and problems of industrial development in the Latvian SSR after World War II, which is illustrated by the example of the building materials industry as one of the bottlenecks in state industry.

The present paper was preceded by research on the structure of the national economy of the Latvian SSR and the process of its recovery during the period from the end of World War II to 1953, conducting in-depth research of one of its sectors - the industry of building materials, paying special attention to the manufacturing process and products, as well as to the key performance indicators.

The result of the study shows that, although strategic importance was given to the production of building materials, as it had to be developed rapidly, its condition was discrepant from the claimed priority during the study period.
\end{abstract}

Keywords: Latvian SSR, national economy, economics, industry, production, building materials.

\section{SUMMARY}

The events of 1940-1941 and World War II radically changed the form and matter of the Latvian economy. After the war, it virtually had to be rebuilt from the ground up by combining the remnants of the pre-war economy with completely new principles of economic activity based on Marxist political economy theory.

Nevertheless, the study of this process is not entirely extraneous to the current historiography. In looking at the renewal and development features of industry in the Latvian SSR, researchers have been focusing mainly on either the most rapidly growing sectors of the Soviet system, such as metalworking, machine and apparatus construction, or the status of the previously leading industries of the former Republic of Latvia (wood and 
food industries). Behind them, an industry that is extremely important in the context of the post-war recovery - the production of building materials - has remained almost unnoticed, although its products served as the material base for all industrial, rural, communal and military sectors of the economy.

The documents stored in the National Archives of Latvia, as well as the periodicals of that time show that, despite the importance of the building material sector, its renewal and development has been atypically difficult and slow, even when compared to light industry and agriculture. The sources show both the obstacles that hindered the development of building materials production and the considerable success of the sector in the first post-war years - from the invention of innovative building materials to world records in glass production. 